University for Business and Technology in Kosovo

UBT Knowledge Center

UBT International Conference

2015 UBT International Conference

Nov 7th, 9:00 AM - 5:00 PM

\title{
Are active labour market policies in Albania a panacea for reducing the youth unemployment?
}

Pranvera Elezi

University of Tirana, pranveraelezi@yahoo.com

Fatmir Memaj

University of Tirana, fmema@yahoo.com

Follow this and additional works at: https://knowledgecenter.ubt-uni.net/conference

Part of the Business Commons

\section{Recommended Citation}

Elezi, Pranvera and Memaj, Fatmir, "Are active labour market policies in Albania a panacea for reducing the youth unemployment?" (2015). UBT International Conference. 35.

https://knowledgecenter.ubt-uni.net/conference/2015/all-events/35

This Event is brought to you for free and open access by the Publication and Journals at UBT Knowledge Center. It has been accepted for inclusion in UBT International Conference by an authorized administrator of UBT Knowledge Center. For more information, please contact knowledge.center@ubt-uni.net. 


\title{
Are active labour market policies in Albania a panacea for reducing the youth unemployment?
}

\author{
Pranvera Elezi ${ }^{1}$, Fatmir Memaj ${ }^{2}$ \\ ${ }^{1,2}$ University of Tirana, Faculty of Economy \\ \{pranveraelezi $\left.{ }^{1}, \mathrm{fmema}^{2}\right\} @$ yahoo.com
}

\begin{abstract}
Youth unemployment is one of the most debatable issues in recent years in Albania and in the European countries. Active labour market policies (ALMP) are designed to help preventing the increase of unemployment rates and improving the matching of labour supply and labour demand. This paper examines the effectiveness of ALMP-s in improving the labour market outcomes of the young people in Albania. The analysis is carried out using micro-data from the National Employment Service and the Labour Force Survey conducted by the Albanian Institute of Statistics. Our findings provide evidence that ALMPs as a way of combating youth unemployment seem to be effective in Albania. However, the results at the macro-level aggregate suggest that only ALMP-s per se cannot be a panacea for reducing youth unemployment given that the unemployment for young people is persistent. Recommendations on improving labour market policies and possible actions are also provided in the paper.
\end{abstract}

Keywords: labour market, youth unemployment, active labour market policies.

\section{Introduction}

High rates of youth unemployment in Europe as well as in Albania, have grappled the policy agenda set of governments. The recent world financial crisis of 2009 has hit the labour market performance in many European countries. Young people trying to get into the labour market face difficulties. One of the key features of the Albanian labour market is the persistency of youth unemployment with high levels of unemployment and the high share of unemployed in long term unemployment. The economists explain that these two issues together will in the long run result in widespread deterioration of human capital, discouragement and labour market withdrawal. The high rates of youth unemployment show only one facet of malfunctioning of Albanian labour market. Youth with a university degree have a high unemployment rate compared to those with primary and secondary education. This might be one of the indices that labour market is not able to absorb the newly educated youth or in other words there exist disequilibrium.

In the literature of labour economics the persistency of unemployment is defined as a tendency of unemployment to be high for quite a while also after temporary unemployment-creating shocks. The depreciation of human capital due to long spells of unemployment is seen as one of the factors causing the persistence of unemployment. The persistence of unemployment among young brings consequences later in life. In Albania, there are fewer opportunities for youth to get work experiences because the majority of enterprises are small ones (based on INSTAT data of the Statistical Business Register, about 90 per cent of enterprises in 2013 were with 1-4 employees). The latest data on labour cost survey in Albania show that enterprises with at least ten employees declare a very neglecting number of apprentices (INSTAT, 2013). As previous job experience plays a crucial role when applying for a job, Albanian youth face this as a first obstacle in their entry into labour market becoming more likely to have lower wages and suffer joblessness again later in life. Starting their career in low paid jobs youth increases the job change rate. On the other side, the employment trajectories of young people are particularly sensitive to the economic cycle. Young people are generally the first to lose their jobs in times of economic contraction and the last to gain employment when the economy rebounds. This is one of the main reasons why young people have been seriously affected by the global economic crisis (ILO, 2011). The transition period from school to work for Albanian youth is estimated to be approximately 2-3 years. In such case, the resulting problem 
becomes even worse, due to the combination of job experience missing, acceptance of low paid jobs, and the high rate of job change. The persistence of youth unemployment in Albania has been associated on the other hand with a high rate of skills mismatch. Recently the government of Albania is emphasising the importance of vocational education and training programmes as driving forces for better job opportunities and job creation especially for youth. The reasons behind the new measures of strengthening the training programmes and the vocational education in Albania are linked with the match between worker characteristics and job requirements, as well as the avoidance of the so-called hysteresis effects of long unemployment spells. Hysteresis is the likelihood that lengthening spells of unemployment become self-perpetuating, as skills erode or grow irrelevant. One of the theories that explain hysteresis is the unemployment duration. Unemployment duration has negative effects on labour demand and labour supply of the unemployed. The longer unemployment duration is the less likely is unemployed workers to be offered jobs because firms hold the belief that the long term unemployed are low quality workers. The longer the unemployment duration the more discouraged the worker will become and the more likely the agent is to drop out of the labour force. Different researchers explain the high rates of youth unemployment in Europe as being caused by the financial crisis of 2009. Indeed the financial crisis explains partly this issue. In Albania youth were facing difficulties to enter labour market during the whole transition period. In figure 1 are presented the youth unemployment rates for Greece, Spain, Italy, Serbia and Albania. We select these countries because they were mostly hit from the latest financial crisis and Greece and Italy are the two countries where live the majority of Albanian emigrants. For the period 2010-2014, youth unemployment rate in Albania is lower than in other countries. The global financial crisis has exacerbated long standing disparities between countries - for instance youth unemployment rates in Spain and Greece have remained at around 20-25 per cent during 2007-2008 and now are above 45 per cent in both countries.

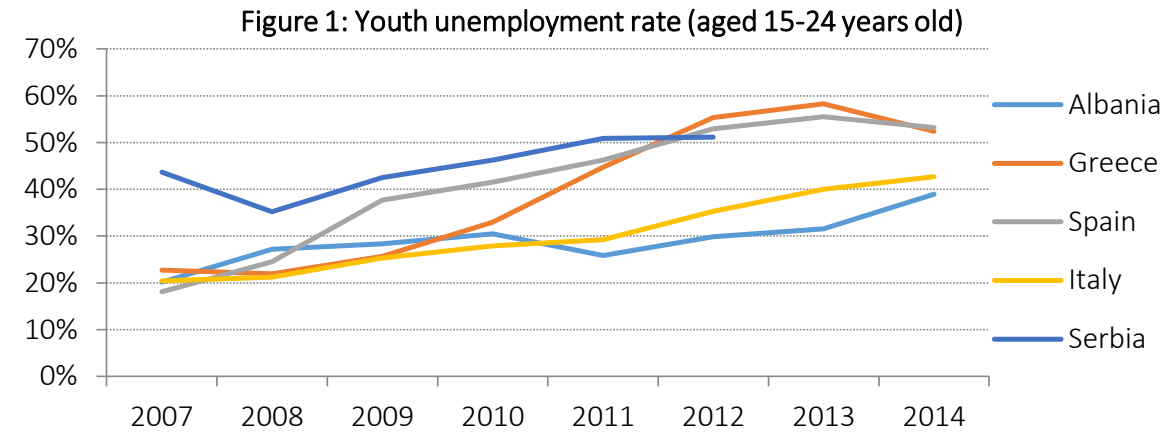

Source: Eurostat Labour Force Survey

Youth unemployment rates vary between countries for a number of reasons including the education system, labour market institutions and the strength of the national economy. In Albania the apprenticeship system is almost inexistent and do not support the transition from school to work. The German model of strong dual apprenticeship system is being established during last two years, but still it is not fully enhances by business.

Young people outside the labour market might be discouraged workers (do not search for a job because of belief that no jobs are available), or students, fulfilling housing tasks, etc. The high percentage of youth not in employment, education or training is an important phenomenon in Albania and most of European countries. Figure 2 below shows the increasing trend of NEET rate for the youth aged 15-29 years old in Albania. According to Labour Force Survey in Albania, the share of youth not in employment, education or training (NEET) increased from 27.4 percent in 2007 to 32.2 per cent in 2009, and then declined to 31.4 per cent in 2010. 
Figure 2: NEET rate in Albania, 2007-2014

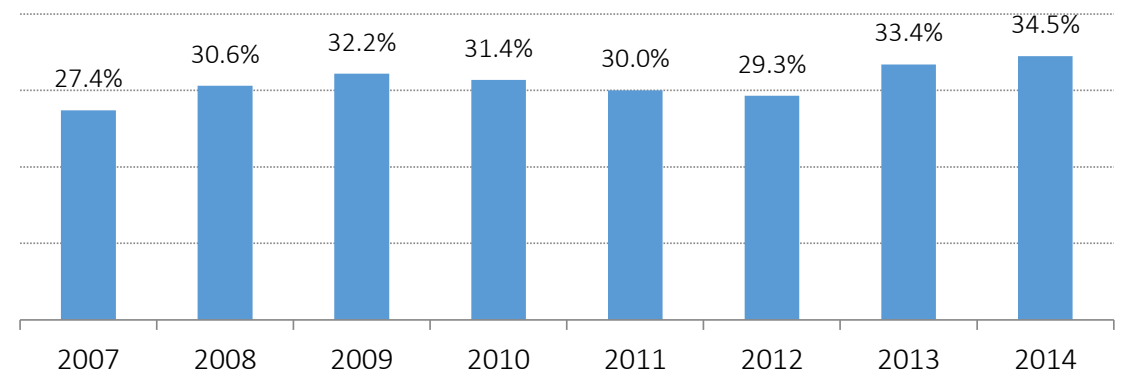

Source: European Training Foundation (ETF) based on Albanian Labour Force Survey 2007-2014

In 2012 the share of young NEET-s was 29.3 per cent, twice the rate found among EU27 countries $(13 \%)$, due to the higher share of youth who are inactive and neither in education nor training. NEET rate and youth unemployment are two related concepts (Sissons and Jones, 2012). The unemployment rate is a measure of those who are out of work, but have looked for work in the past month and are able to start in the next two weeks - as a proportion of the economically active. This can include individuals who are in education. The definition of NEET excludes all those people who are in employment, education or training, but includes some of the economically inactive.

In this paper the three largest active labour market policy programmes - Programme of encouraging employment of unemployed job seekers in difficulty; Programme of encouraging employment through on the job training; and Programme of encouraging employment of unemployed job seekers graduated from Albanian and international universities, through internships in state or private institutions and enterprises - are analysed. The paper is structured as follows: After a brief description of active labour market programmes in Albania, an ALMP analysis at macro-level aggregate is discussed in section 3. Section 4 discusses the results and draws conclusions.

\section{Active labour market programmes in Albania}

Active labour market policies are designed to help preventing the increase of unemployment rates and improving the matching of labour supply and labour demand. Kluve (2006) concludes that there are several indications that training programs do increase participants' post-treatment employment probability, in particular for participants with better labour market prospects and for women. Moreover, Cluve (2006) argues that young people appear to be particularly hard to assist and he suggests that youth programs should be re-designed and given particular attention. According to Cluve and Lehmann (2008), youth unemployment is a serious problem, in particular because some school leavers have not acquired sufficient skills to be employable at a wage that generates a living income. Training measures are meant to enhance the skills of these school leavers as are subsidized wage and job schemes.

The ALMPs in Albania are a combination of labour-supply-oriented and labour-demand -oriented measures implemented through employment promotion programmes. The main underlying principle of these programmes is to reduce unemployment and informality, increase worker employability, and move them into regular non-subsidized employment in the long-term. The rationale for the creation of the employment promotion programs in Albania since their start in 1999, has foreseen the creation of new jobs to decrease unemployment, including youth unemployment and other vulnerable groups. Currently, in Albania there are in place six main employment promotion programmes (EPP) applied by National Employment Service (NES).

1. Programme of encouraging employment of unemployed job seekers in difficulty - it provides financial support to employers who assure temporary employment of unemployed jobseekers in difficulty (long-term unemployed who receive social assistance, individuals who receive unemployment benefits, those entering the labour market for the first time, individuals between the ages of 18-25, individuals over 45 years who do not have more than secondary 
education or its equivalent, people with disabilities, Roma people, and return migrants who face economic problems);

2. Programme of encouraging employment through on the job training - this program financially supports employers who guarantee the training of beneficiaries and recruit at least $50 \%$ of the trainees in the same occupation for an additional period of 6 months.

3. Programme of encouraging employment of unemployed female jobseekers from special groups approved - the program of employment for women aims to integrate marginalized women such as Roma women, former trafficked women, elderly and women suffering disabilities into the labour market. The women entering this program can be enrolled from 1 to 3 years.

4. Programme of encouraging employment of unemployed youth entering the labour market for the first time - this program added in 2012, specifically targets young unemployed who were previously included in the unemployed jobseekers.

5. Programme of encouraging employment of unemployed job seekers graduated from Albanian and international universities, through internships in state or private institutions and enterprises.

6. Programme of encouraging employment through the institutional training - the program provides training for beneficiaries from companies that guarantee employment after the training, or that can show through labour market studies and investigation that the training will be useful for the participants.

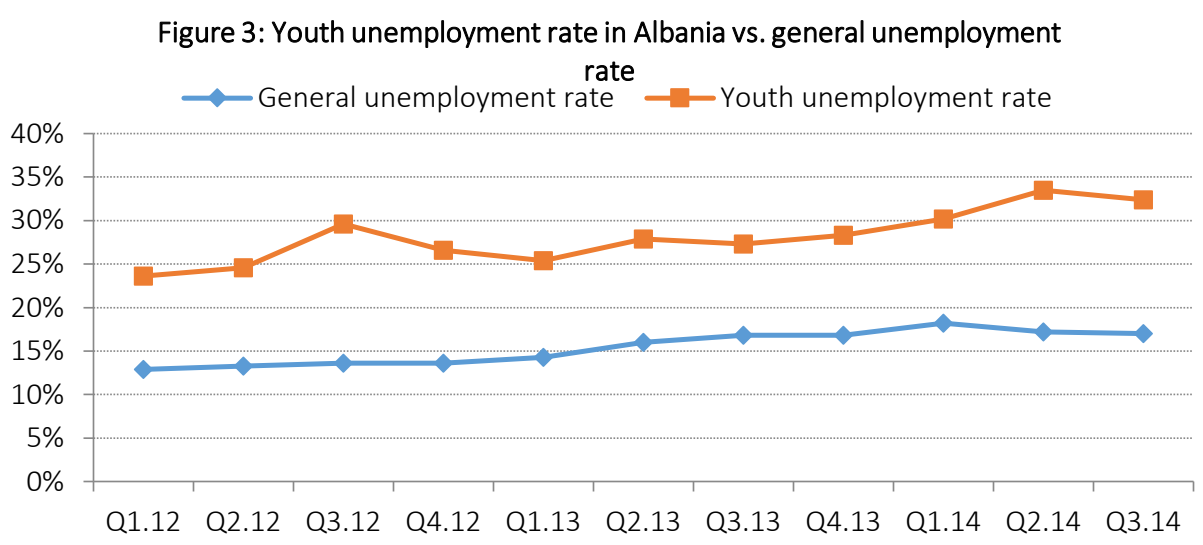

Source: INSTAT (Quarterly Labour Force Survey 2012-2014)

Although the employment promotion programmes rationale is the reduction of unemployment, in Albania the increase of youth unemployment rate makes the effectiveness of employment promotion programmes regarding youth questionable. The youth unemployment rate not only has remained at two digit level, but has been double the rate of general unemployment (See figure 3 above). The ALMP evaluations in Albania are done using propensity score matching methods to examine the impact of EPPs demand side incentives on employment retention on treated group for each of the three following EPP-s: on-the-job training (DCM No. 47), subsidized employment for registered jobseekers in difficulty (DCM No.48) and internship programmes for recently graduates from Albanian and international universities (DCM No. 873). These three programmes have been implemented by NES since 2008 .

Experimental studies and matching studies compare participants with a control group of look-a-likes (Jaap de Koning). In all evaluations (conducted for the periods 2008-2009 23 ; 2010-2011 24 and 2012-

${ }^{23}$ Huibregtse, A. (2010). "Evaluation of the Labour Market Programs (ALMP) based on the D.C.M No. 47/48 and 873."

${ }^{24}$ Elezi, P. (2012). "Assessment of Active Labour Market Programs based on CMDs No. 47/48 and 873." 
$2013^{25}$ ) employment status after one year is used for measuring the outcome results of these three programmes. All programmes in overall show positive impact on employment retention after one year for the treated group compared to the control group.

\section{ALMP analysis from a macro-level perspective}

Despite of the positive outcome results of the matching analyses conducted for measuring the effectiveness of ALMP-s, the labour market situation of young Albanian still remains detrimental. The percentage of unemployed treated by employment promotion programs to average number of registered jobseekers is very low. Across all programmes, during 2012-2013 the percentage of coverage has been $1.0 \%$ falling from $1.5 \%$ during $2010-2011$ and $1.2 \%$ during $2008-2009$. As a result, the expected real impact of these programmes on decreasing unemployment is quite low on the macro level. The coverage of youth unemployed jobseekers in the employment promotion programmes is also low. In 2012-2013, the proportion of youth registered jobseeker participating in the evaluated programmes was only 3.3 percent of all youth registered as unemployment jobseekers.

Each of the three evaluated programmes provides financial incentives to employers in order to provide employment for the registered jobseekers. Measuring the ALMP effectiveness in Albania only based on the micro-level approach is not straightforward. Firstly, the evaluation results assess the employment outcome based on an experimental and matching approach comparing the participants in EPP-s with a control group of look-a-likes. Secondly, the major parts of EPP beneficiaries in Albania are participating on the job-training programmes which are mainly employer-wagesubsidized-oriented. This raises the issue of creating jobs in the low-value-added activities since the subsidized wage is at the official minimum wage level.

The vast majority of EPP beneficiaries are part of on-the-job-training programme, while the economic activities of businesses are manufacturing of wearing apparel and textiles, and construction. On the other hand, the employment sustainability in these economic activities is strongly related either to the international demand in the case of manufacturing of wearing apparel and textiles, or to the seasonality-featured employment such as construction. Thirdly, the economically inactive youth remains invisible and consequently is not benefiting from the activation measures. Given that the economically inactive youth is difficult to be captured and targeted for ALMPs, the increasing focus on this group is substantial. EPP-s beneficiaries are only the registered unemployed jobseeker.

The evaluations of ALMP in Albania do not put emphasise on the ALMP effects due to the limitations imposed by the information in the micro-data files of NES. Given that the EPP-s are providing financial incentives to employers may cause the deadweight loss effect. The deadweight loss effect lowers the effectiveness of ALMP. Lehman and Kluve (2010) point out that the effectiveness of ALMPs might be further undermined by the creaming effect. Creaming effect means that only workers with high employment probabilities are selected in EPPs.

\section{Conclusions}

Albania has a major youth unemployment problem. The youth unemployment rate is associated with unemployment persistence. The lack of apprentice opportunities make Albanian youth face obstacles in their entry into labour market and increases the likelihood to have lower wages and suffer joblessness again later in life.

The main political concerns on high rates of youth unemployment address the human capital deterioration, which in turn creates a vicious circle where youth remain trapped. On the other side, the malfunction of labour market in Albania is strongly affected by the skills mismatch. The high rates of youth unemployment show only one facet of malfunctioning of Albanian labour market. The analysis of youth unemployment rate is not straightforward if it is not extended to other youth issues. NEET rate and youth unemployment are two related concepts and need to be further in depth analysed.

${ }^{25}$ Employment Promotion Programmes in Albania: An assessment of its quality in the formulation and implementation processes (2008-2014)" 
Active labour market policies are designed in Albania to help preventing the increase of unemployment rates and improving the matching of labour supply and labour demand. The rationale for the creation of the employment promotion programs in Albania since their start in 1999, has foreseen the creation of new jobs to decrease unemployment, including youth unemployment and other vulnerable groups. Currently, in Albania there are in place six main employment promotion programmes (EPP) applied by National Employment Service (NES).

Although the employment promotion programmes rationale is the reduction of unemployment, in Albania the increase of youth unemployment rate makes the effectiveness of employment promotion programmes regarding youth questionable. The youth unemployment rate not only has remained at two digit level, but has been double the rate of general unemployment.

Despite of the positive outcome results of the matching analyses conducted for measuring the effectiveness of ALMP-s, the labour market situation of young Albanian still remains detrimental. The vast majority of youth registered jobseekers in EPP-s are mainly in on-the-job-training programme which poses the risk of being stuck in low-wage-employment and in economic sectors that hghly depend on the international demand or seasonality.

The evaluated employment promotion programmes provide financial incentives to employers in order to provide employment for the registered jobseekers. Given that the EPP-s are providing financial incentives to employers may cause the deadweight loss effect. ALMP-s per se cannot be a panacea for reducing youth unemployment given that the unemployment for young people is persistent.

There is a need for improving labour market policies especially regarding to skills development. Despite of the risk of deadweight loss effect, the early intervention in the unemployment spell, especially in the case of disadvantaged young job seekers remains essential.

\section{References}

1. de Koning, J., Peers, Y., "Evaluating ALMP evaluations", SEOR working paper, No. 2007/2

2. Elezi, P. (2012). "Assessment of Active Labour Market Programs based on CMDs No. 47/48 and 873."

3. Employment Promotion Programmes in Albania: An assessment of its quality in the formulation and implementation processes (2008-2014)"

4. Huibregtse, A. (2010). "Evaluation of the Labor Market Programs (ALMP) based on the D.C.M No. $47 / 48$ and 873 ."

5. Kluve J. (2006), "The Effectiveness of European Active Labour Market Policy”, IZA Discussion Paper No. 2018, Bonn

6. Kluve, J., Lehmann, H., Schmidt C.M. (2008). "Disentangling treatment effects of active labour market policies: The role of labour force status sequences.” Labour Economics.

7. Labour Cost Survey in Albania 2013. www.instat.gov.al

8. Meager, N. (2009), The role of training and skills development in active labour market policies. International Journal of Training and Development, 13: 1-18.

9. Sissons, P., and Jones, K., "Lost in transition? The changing labour market and young people not in employment, education or training" May 2012

10. The Prince's Trust (2007) The Cost of Exclusion: Counting the cost of youth disadvantage in the UK, The Prince's Trust

11. Youth employment in Eastern Europe: Crisis within the crisis, 2011. ILO 